Griya Widya: Journal of Sexual and Reproductive Health, 1(1) 2021, 01-13

Available at: https://journal.nurscienceinstitute.id/index.php/griyawidya

EISSN: 2809-6797

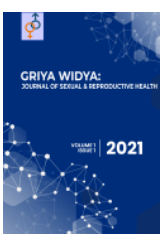

\title{
Prevalensi dan Gambaran Karakteristik Dismenorea pada Remaja
}

\author{
Wahyuni Wahyuni $^{1^{*}}$ \& Ulfah Zulfahmi ${ }^{2}$ \\ ${ }^{1,2}$ Fisioterapi, Fakultas IImu Kesehatan, Universitas Muhammadiyah Surakarta, \\ Surakarta, Indonesia \\ *Email: wahyuni@ums.ac.id
}

Submitted: 2021-08-04

DOI: 10.53088/griyawidya.v1i1.104

Accepted: 2021-12-27

Published: 2021-12-29

\begin{tabular}{|c|c|}
\hline Keywords: & Abstract \\
\hline $\begin{array}{l}\text { Physical activity } \\
\text { Dysmenorrhea } \\
\text { Menstruation } \\
\text { Body mass index } \\
\text { Menstruation } \\
\text { cycle } \\
\text { Menarche. }\end{array}$ & $\begin{array}{l}\text { Background: Dysmenorrhea is a gynecological condition that most commonly } \\
\text { occurs in women of childbearing age. Dysmenorrhea is defined as a paiful } \\
\text { sensation, cramping in the lower abdoment, and is often accompanied by other } \\
\text { symptoms, such as sweating, headache, nausea, vomiting, diarrhea, and } \\
\text { shaking. All of this happens right before or during menstruation. Primary } \\
\text { dysmenorrhea complaints are often experienced by young women under } 25 \\
\text { years old. Dysmenorrhea often results in disruption of activities and social } \\
\text { relationships. Pondok Pesantren Putri Ar-Rohmah is a special Islamic boarding } \\
\text { school for female students aged 13-18 years. At this age, primary } \\
\text { dysmenorrhea complaints often occur. The activities of the students are also } \\
\text { very far from the words of heavy activity, they only recite the recitation, } \\
\text { memorization and formal schooling which is very lacking in physical activity. } \\
\text { Objective: The purpose of this study was to determine the prevalence and } \\
\text { description of the characteristics of primary dysmenorrhoea in adolescents at } \\
\text { Islamic Boarding School Putri Ar-Rohmah Ngawi. } \\
\text { Method: This research was quantitative research with descriptive } \\
\text { observational methods. } \\
\text { Result: From the study, the prevalence of primary dysmenorrhoea in } \\
\text { adolescents in Islamic boarding schools was } 83.1 \% \text {. The highest characteristic } \\
\text { of dysmenorrhoea is caused by lack of physical activity, namely 54.2\% of } \\
\text { respondents are less active and 5.8\% of respondents have sedentary behavior. } \\
\text { Conclusion: The characteristic description that most influences the occurrence } \\
\text { of dysmenorrhoea in students is inadequate physical activity. Meanwhile, the } \\
\text { description of the characteristics of body mass index, age of menarche, } \\
\text { menstrual cycle, and menstrual duration are not the main characteristics that } \\
\text { cause dysmenorrhea in respondents. }\end{array}$ \\
\hline
\end{tabular}

(C) 2021. This work is licensed under a CC BY-SA 4.0 


\section{PENDAHULUAN}

Masa remaja diasumsikan sebagai masa peralihan dari anak-anak menuju dewasa. World Health Organization (WHO) mengategorikan remaja mulai dari usia 10 sampai 19 tahun dengan prevalensi yang tersebar di seluruh dunia mencapai 1,2 milyar orang (WHO, 2018). Sementara itu, menurut pusat data dan informasi, prevalensi remaja di Indonesia mencapai angka 43,5 juta atau $18 \%$ dari total seluruh penduduk di Indonesia (Pusdatin, 2017). Hal ini menunjukkan angka yang cukup tinggi.

Masa remaja merupakan masa kritis manusia yang ditandai pertumbuhan fisik yang cepat, psikososial, perkembangan kognitif dan emosional, serta pematangan seksual dan reproduksi (Lehtimaki \& Schwalbe, 2019). Salah satu tanda pematangan seksual dan reproduksi pada remaja putri adalah mengalami menstruasi. Menstruasi didefinisikan sebagai keluarnya darah secara berkala dari rahim yang terjadi setiap bulan dan sepanjang masa reproduksi aktif seorang wanita (Michael et al., 2020). Siklus menstruasi wanita akan terus berulang mulai dari usia menarche hingga menopause. World Health Organization menyatakan bahwa usia rata-rata remaja yang mengalami menarche adalah usia 12-13 tahun (WHO, 2011). Ketika remaja mengalami menstruasi, sebagian besar dari mereka juga mendapatkan sebuah permasalahan ketika menstruasi datang, yaitu nyeri menstruasi atau dismenorea.

Dismenorea diartikan sebagai sensasi nyeri, kram pada perut bagian bawah, dan sering disertai gejala lain, seperti berkeringat, sakit kepala, mual, muntah, diare, dan gemetar. Semua itu terjadi tepat sebelum atau selama menstruasi (Ju et al., 2014). Dismenorea merupakan kondisi ginekologi yang paling umum terjadi pada wanita di usia subur. Meskipun dismenorea terjadi secara umum, namun masih banyak hal yang belum diketahui oleh masyarakat tentang gangguan dismenorea termasuk diagnosis dan yang memengaruhi (lacovides et al., 2015). Dismenorea terbagi menjadi 2 jenis, yaitu dismenorea primer dan sekunder. Dismenorea primer yaitu dismenorea yang terjadi tanpa adanya kelainan atau penyakit pada organ reproduksi. Sementara dismenorea sekunder merupakan dismenorea yang berhubungan dengan adanya penyakit pada organ reproduksi, seperti endometriosis, adenomiosis, dan mioma uterus (Osuga et al., 2020).

Prevalensi dismenorea primer secara global sangat tinggi dan bervariasi yaitu berkisar antara 45\% hingga 95\% (lacovides et al., 2015). Sebuah studi yang dilakukan di Australia terhadap siswa sekolah menengah atas menemukan bahwa 93\% remaja mengalami desmenorea primer (Ju et al., 2014). Sementara itu, di Indonesia prevalensi dismenorea mencapai $60-70 \%$, dengan angka kejadian dismenorea primer 54,89\% dan dismenorea sekunder 45,11\% (Lail, 2019).

Tingginya angka kejadian dismenorea primer ini dipengaruhi oleh beberapa gambaran karakteristik. Diantara gambaran karakteristik yang menyebabkan dismenorea primer adalah munculnya menarche pada usia dini, riwayat keluarga yang mengalami dismenorea, siklus menstruasi yang lama, merokok, konsumsi alkohol dan kafein, kualitas tidur yang buruk, kebiasaan mengonsumsi makanan tertentu, kurang beraktifitas fisik atau olahraga, obesitas, dan stres (Fernandez-Martinez et al., 2018).

Dismenorea primer dapat memberikan dampak yang cukup signifikan terhadap kualitas hidup seseorang. Mereka akan cenderung mengurangi aktivitas fisik akibat nyeri, kurang percaya diri, dan sulit berkonsentrasi. Hal ini sangat jelas menunjukkan bahwa dismenorea primer sangat mengganggu aktivitas sehari-hari (Kumbhar et al., 2011). Padahal di usia remaja sangat dianjurkan untuk tetap produktif dalam menjalankan aktivitas. Remaja biasanya banyak menjalankan aktivitas sehari-hari dengan komunitas remaja.

Salah satu komunitas remaja yang paling banyak ditemukan adalah di sekolah atau pondok pesantren. Pondok Pesantren Islam Putri Ar-Rohmah Ngawi terletak di wilayah Kabupaten Ngawi Jawa Timur, tepatnya di Dusun Bulakrejo, Desa Katikan, Kecamatan 
Kedunggalar, Kabupaten Ngawi. Pondok Pesantren ini adalah pondok pesantren khusus untuk santriwati dengan jumlah santri sebanyak 448 orang. Usis santri di Pondok Pesantren ini berkisar antara 13 - 18 tahun. Selain belajar ilmu agama, mereka juga belajar sekolah formal dari SMP sampai SMA. Sebutan untuk SMP kelas I adalah Kelas satu, sementara untuk SMA kelas satu adalah kelas empat, jadi jenjang pendidikan di sana dimulai dari kelas satu sampai kelas enam. Seperti sekelompok santri di Pondok Pesantren Islam Putri ArRohmah Ngawi. Para santri memiliki aktivitas belajar dan jadwal yang sangat padat setiap harinya. Berdasarkan survei yang telah dilakukan oleh peneliti, mereka hanya fokus pada menuntut ilmu dan jarang melakukan aktivitas fisik.

Melihat permasalahan di atas, penulis ingin melakukan penelitian dengan judul "Prevalensi dan gambaran karakteristik Dismenorea pada Remaja di Pondok Pesantren Islam Putri Ar-Rohmah Ngawi". Tujuan penelitian ini adalah untuk mengetahui berapakah prevalensi dan apa saja gambaran karakteristik dismenorea primer pada remaja di Pondok Pesantren Islam Putri Ar-Rohmah Ngawi.

\section{METODE}

\section{Jenis dan Desain}

Jenis penelitian yang dilakukan adalah penelitian kuantitatif berupa observasional deskriptif yang bertujuan untuk mencari gambaran fenomena atau -gambaran karakteristik dismenorea pada remaja di suatu populasi tertentu (Masturoh \& Temesvari, 2018). Penelitian ini sudah mendapatkan kelaikan ethic dari Komite Etik Fakultas Kedokteran UMS dengan nomor: 3118/B.1/KEPK-FKUMS/XI/2020. Penelitian dilaksanakan di Pondok Pesantren Islam Putri Ar-Rohmah Ngawi, yang beralamat di Bulakrejo, Katikan, Kecamatan Kedunggalar, Kabupaten Ngawi, Jawa Timur. Penelitian dilakukan bulan September 2020 hingga Januari 2021.

Data dan Sumber Data

Sumber data yang diambil berupa data primer yang didapat dari populasi penelitian. Populasi pada penelitian ini adalah santri di Pondok Pesantren Islam Putri Ar-Rohmah Ngawi sebanyak 448 orang. Teknik pengambilan sampel penelitian dilakukan dengan metode purposive sampling sesuai dengan kriteria inklusi dan eksklusi sebanyak 225 orang. Kriteria Inklusi pada penelitian ini adalah subjek bersedia menjadi responden penelitian, sudah mengalami menstruasi, subjek berusia 11-19 tahun dan bersedia memberikan informasi yang akurat. Adapun kriteria eksklusinya adalah memiliki riyawat penyakit reproduksi.

\section{Teknik Pengumpulan Data}

Teknik pengumpulan data dilakukan dengan menggunakan kuesioner yang dibuat berdasarkan standar peneliti sendiri. Data yang diambil berupa identitas pasien, usia, derajat nyeri dismenore, berat badan, tinggi badan, usia awal menstruasi, derajat melakukan aktivitas fisik, durasi menstruasi, dan lama siklus menstruasi. Pengambilan data dilakukan secara langsung dengan menyebarkan kuesioner dan tetap memperhatikan protokol kesehatan baik bagi responden maupun peneliti. Dalam pengisian kuesioner, responden akan dikumpulkan di ruang kelas kemudian dibimbing oleh enumerator yang membantu dalam proses pengisian kuesioner.

Variabel Dependent (variabel terikat) adalah dismenore primer, variabel Independent (variabel bebas) adalah -gambaran karakteristik dismenorea yaitu Indeks Massa Tubuh (IMT), aktivitas fisik, dan usia menarche,durasi menstruasi, dan siklus menstruasi. Dismenorea primer merupakan kondisi ginekologis yang umum terjadi pada wanita saat menstruasi yaitu nyeri pada rahim yang memengaruhi kualitas hidup (Suzanne et al., 2010). Penentuan dismenorea dilihat dari kategori nyeri yang diukur dengan menggunakan Numeric Rating Scale (NRS). Skala pengukuran dengan angka 0 menunjukkan tidak ada 
nyeri, skala 1-3 nyeri ringan, skala 4-6 merupakan kategori nyeri sedang, dan skala 7-10 adalah nyeri berat. Indeks Massa Tubuh (IMT) merupakan pengukuran antropometri yang biasa digunakan untuk mengetahui status gizi. Indeks Massa Tubuh diukur dengan memasukkan berat badan dan tinggi badan pada rumus berikut :

$$
\text { IMT : } \frac{\text { berat badan }}{(\text { tinggi badan }) 2}
$$

Kategori indeks massa tubuh berdasarkan World Health Organization adalah underweight, normal, overweight, dan obesitas. Underweight apabila IMT kurang dari 18,5 $\mathrm{kg} / \mathrm{m} 2$, normal $18,5-24,9 \mathrm{~kg} / \mathrm{m} 2$, overweight $25-29,9 \mathrm{~kg} / \mathrm{m} 2$, dan obesitas $>30 \mathrm{~kg} / \mathrm{m} 2$.

Aktivitas fisik adalah kegiatan yang melibatkan kontraksi otot rangka dan dilakukan diluar dari aktivitas sehari-hari. Pengukuran aktvitas fisik dikategorikan menjadi empat tingkatan, yaitu sedenter, kurang aktif, aktif, dan sangat aktif. Sedenter apabila seseorang yang tidak melakukan aktivitas fisik dengan intensitas ringan hingga sedang diluar gerakan dasar aktivitas sehari-hari. Kurang aktif yaitu melakukan aktivitas fisik dengan intensitas ringan selama 150 menit, atau aktivitas sedang selama 75 menit dalam satu minggu. Aktif yaitu melakukan aktivitas fisik dengan intensitas sedang selama 150 menit hingga 300 menit setiap minggunya. Sangat aktif yaitu melakukan aktivitas fisik dengan intensitas sedang hingga berat lebih dari 300 menit dalam satu minggu. Durasi menstruasi merupakan waktu yang dibutuhkan ketika fase menstruasi datang yaitu antara 4-7 hari. Pengukuran dilakukan dengan dengan menggunakan kuesioner. Siklus menstruasi adalah siklus perubahan pada reproduksi secara alami yang terjadi berulang-ulang dan melalui beberapa fase selama 2435 hari. Pengukuran siklus menstruasi dilakukan dengan menggunakan kuesioner.

\section{Teknik Analisis Data}

Teknik analisis data yang digunakan pada penelitian ini adalah analisis univariat. Distribusi frekuensi setiap variabel yang diperiksa adalah karakteristik responden berdasarkan usia, usia menarche, indeks massa tubuh, aktivitas fisik, durasi menstruasi, dan siklus menstruasi. Selain itu, peneliti juga akan memeriksa karakteristik dismenorea yang berupa tingkat keparahan nyeri dan durasi nyeri.

\section{HASIL}

Penelitian dilaksanakan di Pondok Pesantren Islam Putri Ar-Rohmah Ngawi yang beralamat di Bulakrejo, Katikan, Kecamatan Kedunggalar, Kabupaten Ngawi, Jawa Timur. Pengambilan data dilakukan pada tanggal 20 Desember 2020, dengan membagikan informed consent dan kuesioner kepada santri. Dalam pengisian kuesioner, santri dibimbing oleh enumerator yang membantu dalam proses penelitian. Total populasi penelitian adalah 448 santri dan responden yang didapatkan berdasarkan kriteria inklusi dan eksklusi adalah 225 orang, dengan rincian 20 orang tidak setuju menjadi responden, 13 orang berusia dibawah 11 tahun dan diatas 19 tahun, 76 orang belum mengalami menstruasi, dan 114 orang tidak mengisi kuesioner dengan lengkap. Uji validitas kuesioner dilakukan dengan dengan menggunakan validitas konstruk, dengan hasil setiap butir soal adalah valid. 
Tabel 1. Karakteristik Responden

\begin{tabular}{|c|c|c|}
\hline Karakteristik & Jumlah & $\%$ \\
\hline \multicolumn{3}{|l|}{ Prevalensi } \\
\hline Dismenorea & 187 & 83,1 \\
\hline Tidak Dismenorea & 38 & 16,9 \\
\hline \multicolumn{3}{|l|}{ Usia } \\
\hline 11-13 & 54 & 23,9 \\
\hline $14-16$ & 116 & 51,6 \\
\hline 17-19 & 55 & 24,5 \\
\hline \multicolumn{3}{|l|}{ IMT } \\
\hline Underweight & 82 & 36,4 \\
\hline Normal & 132 & 58,7 \\
\hline Overweight & 9 & 4 \\
\hline Obesitas & 2 & 0,9 \\
\hline \multicolumn{3}{|l|}{ Aktivitas Fisik } \\
\hline Sedenter & 13 & 5,8 \\
\hline Kurang Aktif & 122 & 54,2 \\
\hline Aktif & 90 & 40 \\
\hline Sangat Aktif & 0 & 0 \\
\hline \multicolumn{3}{|l|}{ Usia Menarche } \\
\hline $9-10$ & 10 & 4,5 \\
\hline $11-13$ & 189 & 84 \\
\hline $14-16$ & 26 & 11,5 \\
\hline \multicolumn{3}{|l|}{ Durasi Menstruasi } \\
\hline$<4$ hari & 8 & 3,6 \\
\hline 4-7 hari & 183 & 81,3 \\
\hline$>7$ hari & 34 & 15,1 \\
\hline \multicolumn{3}{|l|}{ Siklus Menstruasi } \\
\hline$<28$ hari & 59 & 26,2 \\
\hline 28-35 hari & 145 & 64,4 \\
\hline$>35$ hari & 21 & 9,3 \\
\hline \multicolumn{3}{|l|}{ Tingkat Nyeri } \\
\hline Nyeri Ringan & 2 & 1,1 \\
\hline Nyeri Sedang & 148 & 79,1 \\
\hline \multirow[t]{2}{*}{ Nyeri Berat } & 37 & 19,8 \\
\hline & 225 & 100 \\
\hline
\end{tabular}

Tabel 1 menggambarkan prevalensi dan karakteristik responden. Prevalensi dismenore di Pondok Pesantren Putri Ar-Rohmah adalah 83.1\%. Berdasarkan usia, didapatkan hasil bahwa rata-rata responden memiliki usia 14-16 tahun yang berjumlah 116 (51,6\%). Usia terbanyak dari responden adalah usia 16 tahun yang berjumlah 47 orang.

Hasil data yang diperoleh berdasarkan kriteria index massa tubuh, didapatkan bahwa rata-rata responden memiliki indeks massa tubuh yang normal, yaitu sebesar $58,7 \%$ dan indeks massa tubuh yang kurang (underweight) adalah sebesar $36,4 \%$. Sementara itu, tidak banyak responden yang memiliki indeks massa tubuh diatas normal (overweight) dan obesitas. Berdasarkan aktivitas fisik, ditemukan bahwa masih banyak responden yang memiliki aktivitas fisik yang kurang yaitu sebanyak 122 orang atau sebesar $54,2 \%$. Terdapat pula responden yang memiliki kebiasaan hidup sedenter yaitu sebesar $5,8 \%$. Selain itu, responden penelitian tidak ada yang melakukan aktivitas fisik dengan berat. Berdasarkan 
usia menarche dan didapatkan hasil bahwa rata-rata responden mengalami menstruasi pertamakali pada usia 11-13 tahun dan paling sedikit adalah di usia 9-10 tahun yaitu sebanyak 10 orang. Karakteristik responden berdasarkan durasi menstruasi, menunjukkan bahwa rata-rata durasi menstruasi responden adalah 4-7 hari sebanyak 183 orang dengan presentase $81,3 \%$. Sementara durasi menstruasi kurang dari 4 hari dan lebih dari 7 hari, masing-masing sebanyak 8 orang $(3,6 \%)$ dan 34 orang $(15,1 \%)$. Berdasarkan siklus menstruasi menunjukkan hasil bahwa siklus menstruasi rata-rata responden adalah 28-35 hari. Responden yang memiliki siklus menstruasi kurang dari 28 hari sebanyak 59 orang dengan presentase $26,2 \%$ dan lebih dari 35 hari sebanyak 21 orang dengan presentase $9,3 \%$. Berdasarkan nyeri menstruasi atau dismenorea, didapatkan hasil 148 responden mengalami nyeri sedang $(79,1 \%), 2$ responden mengalami nyeri ringan $(1,1 \%)$, dan 37 responden mengalami nyeri berat $(19,8 \%)$.

\section{PEMBAHASAN}

Berdasarkan temuan karakteristik responden, dapat diketahui bahwa jumlah responden adalah 225 orang mulai dari usia 11 tahun hingga 19 tahun sesuai dengan kriteria remaja. Berdasarkan sebuah penelitian yang dilakukan di Jakarta Pusat pada tahun 2015, dismenorea lebih sering terjadi pada usia remaja dibanding dengan usia yang lain. Prevalensi dismenorea pada remaja di Jakarta Pusat mencapai angka $87,5 \%$, dimana $20 \%$ responden mengalami nyeri ringan, $64,76 \%$ nyeri sedang, dan $14.76 \%$ nyeri berat (Juniar, 2015). Pada penelitian lain juga ditemukan bahwa prevalensi dismenorea banyak terjadi pada perempuan yang belum menikah dibanding dengan perempuan yang sudah menikah. Hal ini disebabkan karena perempuan yang belum menikah dan di usia muda lebih sering mengalami stres pada kehidupan sehari-hari akibat sekolah dan kerja. Selain itu, perempuan yang sudah menikah akan membawa perubahan fisiologi pada genitalian maupun perubahan psikis yang lebih positif (Hassan, 2011).

Prevalensi dismenorea primer di Pondok Pesantren Putri Ar-Rohmah Ngawi mencapai angka 187 dari 225 responden atau setara dengan 83,1\%. Angka ini menunjukkan prevalensi yang cukup tinggi dengan tingkat keparahan nyeri yang bervariasi. Seperti hasil penelitian yang telah dilakukan pada 460 siswa sekolah menengah khusus perempuan di Ibadan, Nigeria, yang menunjukkan bahwa terdapat prevalensi dismenorea yang tinggi yaitu sebesar 73\%. Dari 335 siswa yang mengalami dismenorea, 37,5\% diantaranya mengalami nyeri ringan, $43,8 \%$ nyeri sedang, dan $18,8 \%$ nyeri berat (Femi-Agboola et al., 2017).

Tingginya angka prevalensi ini tentu disebabkan oleh faktor yang menyebabkan terjadinya dismenorea. Setiap responden memiliki gambaran karakteristik yang berbeda, karena berdasarkan dari hasil penelitian terdapat responden yang memiliki karakteristik yang sama namun kejadian dismenoreanya berbeda. Hal ini terjadi karena presepsi setiap individu terhadap nyeri bersifat subjektif sehingga menghasilkan respon nyeri yang bervariasi. Nyeri yang dirasakan oleh setiap individu ini berbeda-beda karena dipengaruhi oleh faktor penyebab nyeri tersebut (Kusumaningrum et al., 2019). Penelitian lainnya telah mengungkap bahwa dismenorea juga dipengaruhi oleh beberapa faktor lain seperti kondisi psikologis remaja. Di tengah kegiatannya yang cukup padat, remaja cenderung mengalami stress dan mengalami dismenorea. Stress ini dapat memengaruhi hormon pada organ reproduksi. Mekanisme hubungan stress dengan terjadinya dismenorea belum sepenuhnya dipahami. Namun menurut penelitian, orang yang mengalami stress akan mengalami respon neuroendokrin. Kortisol yang diatur oleh corticotrophin releasing hormone (CRH) sebagai respon stres regulator di hipotalamus utama akan memediasi sekresi melalui hipofisis. Akibatnya hormon adrenokortikotrofik (ACTH) dan progesteron yang berperan dalam perkembangan folikel dapat terganggu karena hormon perangsang folikel dan kerusakan hormon luteinizing. Kondisi ini dapat mempengaruhi sintesis prostaglandin PGE2 
dan PGF2 serta pengikatannya pada reseptor miometrium yang akan mempengaruhi kontraksi dari uterus sehingga terjadilah dismenorea (Maryam et al., 2016).

Tingginya angka prevalensi yang ditemukan pada populasi ini juga menyebabkan dampak pada kualitas hidup santri. Mereka cenderung lebih mengurangi aktivitas fisik akibat ketidaknyamanan dan nyeri yang dirasakan saat menstruasi datang. Selain itu, beberapa santri juga tidak menghadiri kegiatan pondok saat mengalami dismenorea. Hal ini sama seperti penelitian sebelumnya yang menemukan bahwa $27 \%$ remaja yang mengalami dismenorea akan terganggu kegiatan yang dilakukan pada posisi berdiri. Kemudian $24,45 \%$ lainnya menyatakan bahwa dismenorea sangat memengaruhi kualitas kehadiran di sekolah, terutama perhatian dan konsentrasi dalam kegiatan ekstra kulikuler (Ahuja et al., 2016).

Adanya temuan prevalensi dismenorea yang cukup tinggi dan dampak yang ditimbulkan, maka perlu dilakukan suatu upaya atau pencegahan sehingga menurunkan risiko terjadinya dismenorea. Salah satu upaya yang harus dilakukan adalah dengan melakukan aktivitas fisik atau exercise secara rutin. Salah satu bentuk aktivitas fisik berupa exercise yang dapat dilakukan adalah lathan penguluran dan latihan penguatan. Latihan ini bisa dilakukan 3 kali dalam satu minggu, selama 10-15 menit setiap latihan (Bustan et al., 2018). Aktivitas fisik yang dilakukan secara rutin, diharapkan dapat meminimalisir keluhan terjadinya dismenorea primer. Aktifitas aerobik juga sangat baik untuk mengurangi nyeri yang diakibatkan oleh dismenore

Rata-rata keseluruhan responden, mempunyai indeks massa tubuh yang normal, namun masih banyak terdapat indeks massa tubuh dengan kategori underweight. Responden yang mengalami dismenorea, $34,2 \%$ diantaranya memiliki indeks massa tubuh dengan kategori underweight, 4,3\% overweight, $1,1 \%$ obesitas dan $60,4 \%$ lainnya normal. Hal ini dapat disimpulkan bahwa dalam penelitian ini, indeks massa tubuh bukan merupakan gambaran karakteristik utama yang menyebabkan dismenorea primer pada remaja. Seperti pada penelitian yang dilakukan oleh Khodakarami et al. (2015), yang menyatakan bahwa tidak ada hubungan signifikan antara indeks massa tubuh dengan kejadian dismenorea pada remaja. Pada penelitian tersebut, kejadian dismenorea lebih tinggi ditemukan pada kelompok remaja yang memiliki indeks massa tubuh normal dibanding dengan yang lainnya (Khodakarami et al,. 2015). Hal ini dapat disebabkan karena wanita yang sebelumnya memiliki indeks massa tubuh underweight, mengalami kenaikan berat badan rata-rata 1,7 $\mathrm{kg} /$ tahun sehingga kategori BMI akan berubah menjaid normal. Namun, wanita tersebut masih memiliki risiko dismenorea $30 \%$ lebih tinggi. Demikian pula, pada wanita overweight atau obesitas yang mengalami penurunan berat badan menjadi normal. Mungkin kekurangan berat badan memberikan dampak yang lebih kuat dan bertahan lama pada fungsi ovarium pada usia lebih dini atau bahwa kelompok wanita ini mungkin memiliki kondisi mendasar lainnya (Ju et al., 2015).

Berbeda dengan penelitian yang dilakukan oleh Widayanti \& Widawati (2018), yang menyatakan bahwa terdapat hubungan antara indeks massa tubuh terhadap dismenorea primer. Pada hasil penelitian ini, responden dengan indeks massa tubuh melebihi normal memiliki risiko yang lebih tinggi untuk mengalami dismenorea primer yaitu sebesar $56 \%$ dibanding dengan responden yang memiliki indeks massa tubuh yang normal. Hal ini terjadi karena adanya jaringan lemak berlebih yang dapat menyebabkan terjadinya hiperplasia pembuluh darah (tekanan pembuluh darah oleh jaringan lemak) pada organ reproduksi wanita sehingga darah yang seharusnya mengalir saat menstruasi menjadi terganggu. Terganggunya aliran darah akibat jaringan lemak ini menimbulkan terjadinya dismenorea (Widayanti \& Widawati, 2018).

Adapun penelitian lain yang menyatakan bahwa seseorang yang memiliki indeks massa tubuh dibawah normal atau underweight memiliki risiko yang lebih tinggi dibanding dengan seseorang yang memiliki indeks massa tubuh normal (Chauhan \& Kala, 2012). Seseorang dengan indeks massa tubuh katergori underweight menunjukkan adanya kekurangan 
asupan gizi sehingga memengaruhi pertumbuhan dan fungsi organ tubuh. Hal ini akan menyebabkan terganggunya fungsi reproduksi pada remaja. Selain itu status gizi yang kurang dapat menyebabkan kondisi tubuh lemah den menyebabkan penurunan terhadap ambang nyeri (Lasmi et al., 2015).

Berdasarkan hasil data kegiatan aktivitas fisik, responden cenderung kurang aktif atau bahkan sedenter. Hal ini disebabkan karena kegiatan yang dilakukan di pondok pesantren cenderung monoton dan hanya fokus terhadap akademik dan kegiatan muroja'ah atau menghafal Al-Qur'an. Belum ada kegiatan aktif lainnya yang melibatkan pergerakan fisik seperti jalan santai, senam, dan aktivitas lainnya. Hal ini menunjukkan bahwa aktivitas fisik yang kurang merupakan salah satu yang memengaruhi terjadinya dismenorea.

Hasil penelitian lainnya yang mendukung penelitian ini dilakukan oleh Kusumaningrum et al. (2019), yang menyatakan bahwa terdapat hubungan antara aktivitas fisik dengan dismenorea primer pada remaja putri. Sebagian besar remaja putri yang melakukan aktivitas fisik berat mengalami dismenorea ringan (22,1\%). Sedangkan remaja putri dengan aktivitas fisik ringan paling banyak mengalami dismenorea sedang hingga berat $(23,4 \%)$.

Risiko terjadinya dismenorea akan semakin meningkat ketika seseorang kurang melakukan aktivitas fisik. Hal ini terjadi karena saat menstruasi, oksigen tidak dapat didistribusikan secara efektif ke dalam pembuluh darah di organ reproduksi sehingga menyebabkan vasokonstriksi (Kusumaningrum et al., 2019). Dismenorea juga diakibatkan karena peningkatan kontraksi otot pada rahim yang diinervasi oleh sistem saraf simpatis. Jika seseorang melakukan banyak aktivitas fisik dan exercise, akan dapat menurunkan kerja saraf simpatis sehingga intensitas dismenorea dapat menurun. (Kusumaningrum et al., 2019). Aktivitas fisik juga dapat meningkatkan pelepasan beberapa neurotransmiter termasuk endorfin dan dopamin, dimana neurotransmiter ini merupakan opiat alami dalam tubuh yang dapat meningkatkan ambang nyeri sehingga intensitas dan gambaran karakteristik dismenorea dapat berkurang (Bavil et al., 2018).

Berdasarkan hasil data penelitian, responden yang mengalami dismenorea sebagian besar mengalami menstruasi pertama kali paling banyak di usia 12 tahun dengan presentase sebesar 43,9\%, kemudian 11 tahun (21,9\%) dan 13 tahun (17,6\%). Usia menarche secara normal terjadi berkisar antara usia 11 tahun hingga 13 tahun. Oleh karena itu sebagian besar responden memiliki usia menarche yang normal. Namun masih banyak pula yang mengalami dismenorea. Hal ini menunjukkan bahwa pada penelitian ini usia menarche bukan satu-satunya gambaran karakteristik yang menyebabkan dismenorea.

Kural et al.,( 2015), mengatakan bahwa tidak ada hubungan yang signifikan antara usia menarche dengan dismenorea primer. Hal senada juga dilakatakn oleh Akbarzadeh et al. (2017), bahwa tidak ada hubungan antara usia menarche dengan kejadian dismenorea. Namun, pada penelitian tersebut ditemukan adanya hubungan antara usia menarche dengan onset dari dismenorea. Hal ini disebabkan karena indikator gangguan adaptasi psikososial di antara anak perempuan berusia 13 hingga 19 tahun (Akbarzadeh et al,. 2017)

Hasil penelitian ini berkebalikan dengan penelitian yang dilakukan oleh Charu et al. (2012) yang menyatakan bahwa terdapat hubungan antara usia menarche dengan dismenorea primer pada remaja. Usia menarche dini dapat meningkatkan risiko terjadinya dismeorea primer. Hal ini disebabkan oleh paparan hormon prostaglandin yang lebih lama sehingga menyebabkan dismenorea pada seseorang yang mengalami usia menarche dini (Charu et al., 2012).

Berdasarkan hasil penelitian telah diketahui bahwa responden baik keseluruhan maupun yang mengalami dismenorea, rata-rata memiliki siklus menstruasi 28 hingga 35 hari. Sementara itu, hasil penelitian mengenai durasi menstruasi didapatkan bahwa ratarata durasi menstruasi responden adalah 4-7 hari. Siklus menstruasi dan durasi mentruasi ini dianggap siklus dan durasi yang normal. Sehingga dalam penelitian ini, ditemukan bahwa 
siklus menstruasi dan durasi menstruasi bukan menjadi gambaran karakteristik utama yang memengaruhi terjadinya dismenorea.

Responden yang memiliki siklus menstruasi normal masih berisiko tinggi mengalami dismenorea. Karena Siklus menstruasi setiap orang dapat berubah-ubah menjadi tidak teratur sesuai dengan kondisi tubuh. Keteraturan siklus menstruasi ini dapat dikaitkan dengan aktivitas fisik yang remaja lakukan. Menurut penelitian mengenai hubungan aktivitas fisik dan keteraturan menstruasi didapatkan bahwa pola sedenter dan beraktifitas fisik sangat berat akan memengaruhi siklus menstruasi karena berhubungan dengan kadar lemak di dalam tubuh. Kadar lemak dalam tubuh dapat berfungsi sebagai pembentukan hormon. Jika kadar lemak terlalu sedikit atau terlalu banyak, maka akan memengaruhi hormon sehingga siklus menstruasi tidak teratur (Kurniawan et al, 2016). Keterbatasan pada penelitian ini adalah belum mencakup -gambaran karakteristik lain seperti stress, riwayat dismenorea pada keluarga, dan frekuensi mengonsumsi kafein, dan lainnya yang dapat memengaruhi terjadinya dismenorea primer pada responden.

\section{SIMPULAN}

\section{Kebaruan dan Kontribusi}

Berdasarkan hasil data dan pembahasan, dapat disimpulkan bahwa prevalensi dismenorea primer pada remaja di Pondok Pesantren Putri Ar-Rohmah Ngawi adalah sebanyak 187 dari 225 orang atsau 83,1\%. Gambaran karakteristik yang paling memengaruhi terjadinya dismenorea pada santri adalah aktivitas fisik yang kurang. Sementara itu, gambaran karakteristik indeks massa tubuh, usia menarche, siklus menstruasi, dan durasi menstruasi bukan merupakan gambaran karakteristik utama yang menyebabkan terjadinya dismenorea pada responden.

\section{Keterbatasan Penelitian}

Pada penelitian ini memiliki keterbatasan yaitu belum mencakup faktor risiko lain yang dapat menyebabkan dismenorea. Faktor risiko tersebut antara lain faktor psikologis, riwayat mengonsumsi kafein, genetik, dan lain sebagainya.

\section{Implikasi dan Saran}

Penelitian ini diharapkan dapat menjadi referensi bagi peneliti lain dan menjadi pedoman untuk memberikan edukasi pada remaja mengenai pentingnya mengurangi faktor risiko terjadinya dismenorea. Saran yang dapat diberikan dalam penelitian ini adalah pertama, remaja dianjurkan untuk meningkatkan aktivitas fisik sebagai upaya penurunan faktor risiko terjadinya dismenorea. Kedua, pihak pesantren atau pondok memberikan penambahan kegiatan yang berkaitan dengan aktivitas fisik. Penambahan kegiatan tersebut dapat diatur dalam jadwal secara terstruktur. Terakhir, peneliti selanjutnya dapat menambahkan variabel penelitian yang mencakup faktor risiko lain penyebab terjadinya dismenorea.

\section{DAFTAR PUSTAKA}

Ahuja, A., Sharma, M. K., \& Singh, A. (2016). Impact of Dysmenorrhea on Quality of Life of Adolescent Girls of Chandigarh [Dampak Dismenorea terhadap kualitas hidup pada remaja perempuan di Chandigarh]. Journal of Child and Adolescent Behaviour, 4(3), 1-5. https://doi.org/10.4172/2375-4494.1000295

Akbarzadeh, M., Tayebi, N., \& Abootalebi, M. (2017). The Relationship Between Age at Menarche and Primary Dysmenorrhea in Female Students of Shiraz Schools [Hubungan antara usia menarche dan dismenorea primer pada siswa perempuan di Sekolah Shiraz]. Shiraz E Medical Journal, 18(9), 9-11. 
https://doi.org/10.5812/semj.14520

Al-Matouq, S., Al-Mutairi, H., Al-Mutairi, O., Abdulaziz, F., Al-Basri, D., Al-Enzi, M., \& Al-Taiar, A. (2019). Dysmenorrhea among High-School Students and its Associated Factors in Kuwait [Dismenorea pada Siswa Sekolah Menengah dan Faktor yang Memengaruhi di Kuwait]. BMC Pediatrics, 19(1), 1-12. https://doi.org/10.1186/s12887-019-1442-6

Barcikowska, Z., Rajkowska-Labon, E., Grzybowska, M. E., Hansdorfer-Korzon, R., \& Zorena, K. (2020). Inflammatory Markers in Dysmenorrhea and Therapeutic Options [Tanda Inflamasi pada Dismenorea dan Pilihan Terapi]. International Journal of Environmental Research and Public Health, 17(4), 1-14. https://doi.org/10.3390/ijerph17041191

Bavil, D. A., Dolatian, M., Mahmoodi, Z., \& Baghban, A. A. (2018). A comparison of physical activity and nutrition in young women with and without primary dysmenorrhea [Perbandingan Aktivitas Fisik dan Nutrisi pada Wanita Muda dengan atau tanpa Dismenorea] [version 1; referees: 2 approved, 1 approved with reservations]. F1000Research, 7(May), 1-12. https://doi.org/10.12688/f1000research.12462.1

Bustan, M. N., Seweng, A., \& Ernawati. (2018). Abdominal Stretching Exercise in Decreasing Pain of Dysmenorrhea among Nursing Students [Latihan Penguluran Abdominal terhadap Penurunan Nyeri Dismenorea pada Mahasiswa Perawat]. Journal of Physics: Conference Series, 1028(1). https://doi.org/10.1088/1742-6596/1028/1/012103

Charu, S., Amita, R., Sujoy, R., \& Thomas, G. A. (2012). "Menstrual Characteristics" and "Prevalence and Effects of Dysmenorrhea" on Quality of Life of Medical Students ["Karakteristik Menstruasi" dan "Prevalensi dan Efek Dismenorea" pada Kualitas Hidup Mahasiswa Medis]. International Journal of Collaborative Research on Internal Medicine and Public Health, 4(4), 276-294.

Chauhan, M., \& Kala, J. (2012). Relation between Dysmenorrhea and Body Mass Index in Adolescents with Rural Versus Urban Variation [Hubungan Antara Dismenorea dan Indeks Massa Tubuh pada Remaja di Pedesaan dan Perkotaan]. Journal of Obstetrics and Gynecology of India, 62(4), 442-445. https://doi.org/10.1007/s13224-012-01717

Clemente1, A. P. G., Santos, C. D. L., Benedito-Silva, A. A., \& Sawaya, A. L. (2011). Body Mass Index of Adolescents : Comparison Among Different References [Indeks Massa Tubuh Remaja : Perbandingan antara Refensi Berbeda] . 29(2), 171-177.

Femi-Agboola, D., Sekoni, O., \& Goodman, O. (2017). Dysmenorrhea and Its Effects on School Absenteeism and School Activities among Adolescents in Selected Secondary Schools in Ibadan, Nigeria [Dismenorea dan Dampak terhadap Ketidakhadiran di Sekolah dan Aktivitas Sekolah pada Siswa Remaja Sekolah Menengah Terpilih di Ibadan, Nigeria]. Nigerian Medical Journal, 58(4), 143. https://doi.org/10.4103/nmj.nmj_47_17

Fernández-Martínez, E., Onieva-Zafra, M. D., \& Laura Parra-Fernández, M. (2018). Lifestyle and Prevalence of Dysmenorrhea among Spanish Female University Students [Gaya Hidup dan Prevalensi Dismenorea pada Mahasiswa Wanita Spanyol]. PLOS ONE, 13(8), 1-11. https://doi.org/10.1371/journal.pone.0201894

Hassan, M. H. Bin. (2011). Perbedaan Angka Kejadian Dysmenorrhea Primer Antara Wanita Yang Sudah Menikah Dengan Wanita Yang Belum Manikah. 3-11.

lacovides, S., Avidon, I., \& Baker, F. C. (2015). What We Know About Primary Dysmenorrhea Today: A Critical Review [Apa yang Kita Tahu tentang Dismenorea Primer: Critical Review]. Human Reproduction Update, 21(6), 762-778. https://doi.org/10.1093/humupd/dmv039

Jones, R. E., \& Lopez, K. H. (2014). Human Reproductive Biology. In Principles of GenderSpecific Medicine (4th ed., Vol. 1). https://doi.org/10.1016/B978-0124409057/50314-5 
Ju, H., Jones, M., \& Mishra, G. (2014). The Prevalence and Risk Factors of Dysmenorrhea [Prevalensi dan Faktor Risiko Dismenorea]. Epidemiologic Reviews, 36(1), 104-113. https://doi.org/10.1093/epirev/mxt009

Ju, H., Jones, M., \& Mishra, G. D. (2015). A U-Shaped Relationship between Body Mass Index and Dysmenorrhea: A Longitudinal Study [Hubngan antara Indeks Massa Tubuh dan Dismenorea: Penelitian Longitudinal]. 1-12. https://doi.org/10.1371/journal.pone.0134187

Juniar, D. (2015). Epidemiology of Dysmenorrhea among Female Adolescents in Central Jakarta [Epidemiologi Dismenorea antara Remaja Wanita di Jakarta Pusat]. Makara Journal of Health Research, 19(1). https://doi.org/10.7454/msk.v19i1.4596

Khodakarami, B., Masoumi, S. Z., Faradmal, J., Saadati, M., Nazari, M., Sharifi, F., \& Shakhbabaei, M. (2015). The Severity of Dysmenorrhea and its Relationship with Body Mass Index among Female Adolescents in Hamadan , Iran [Keparahan Dismenorea dan Hubungan dengan Indeks Massa Tubuh pada Remaja Wanita di Hamadan, Iran]. Journal Of Midwefery and Reproductive Health, 3(4), 444-450.

Krohmer, R. W. (2011). The Reproductive System. New York: Chelsea House.

Kumbhar, S. K., Reddy, M., B, S., K, R. R., K, D. B., Balkrishna, C., \& Pradesh, A. (2011). Prevalence of Dysmenorrhea Among Adolescent Girls ( 14-19 Yrs ) of Kadapa District and Its Impact on Quality of Life : a Cross Study [Prevalensi Dismenorea pada Remaja Wanita (usia 14-19) di Kota Kadapa dan Dampak terhadap Kualitas Hidup: Cross Study] . National Journal of Community Medicine, 2(2), 265-268.

Kural, M., Joshi, T., Patil, A., Noor, N., \& Pandit, D. (2015). Menstrual characteristics and prevalence of dysmenorrhea in college going girls [Karakteristik Menstruasi dan Prevalensi Dismenroea pada Mahasiswa Kuliah]. Journal of Family Medicine and Primary Care, 4(3), 426. https://doi.org/10.4103/2249-4863.161345

Kurniawan, A. F., Trisetiyono, Y., \& Pramono, D. (2016). Pengaruh Olahraga Terhadap Keteraturan Siklus Menstruasi pada Mahasiswi Fakultas IImu Keolahragaan Universitas Negeri Semarang Tahun 2016. Diponegoro Medical Journal (Jurnal Kedokteran Diponegoro), 5(4), 298-306.

Kusumaningrum, T., Nastiti, A. A., Dewi, L. C., \& Lutfiani, A. (2019). The Correlation between Physical Activity and Primary Dysmenorrhea in Female Adolescents [Hubungan antara Aktivitas Fisik dan Dismenorea pada Remaja Wanita]. Indian Journal of Public Health Research and Development, 10(8), 2559-2563. https://doi.org/10.5958/09765506.2019.02252.6

Lail, N. H. (2019). Hubungan Status Gizi, Usia Menarche dengan Dismenorea pada Remaja Putri Di SMK K Tahun 2017. Jurnal Ilmiah Kebidanan Indonesia, 9(02), 88-95. https://doi.org/10.33221/jiki.v9i02.225

Lasmi, K. K. H., Wibawa, A., \& Muliarta, I. M. (2015). Hubungan Antara Indeks Massa Tubuh (IMT) Kategori Underweight dengan Tingkat Nyeri Dysmenorrhea Primer pada Remaja Putri Sekolah Menengah Pertama. Majalah IImiah Fisioterapi Indonesia, 5(3), 27-30.

Lehtimaki, S., \& Schwalbe, N. (2019). Adolescent Health: The missing population in Universal Health Coverage. 1-32.

Lghoul, S., Loukid, M., \& Hilali, M. K. (2020). Prevalence and Predictors of Dysmenorrhea among a Population of Adolescent's Schoolgirls (Morocco) [Prevalensi dan Prediksi Dismenorea pada Populasi Remaja Sekolah Wanita (Morocco)] . Saudi Journal of Biological Sciences, 27(7), 1737-1742. https://doi.org/10.1016/j.sjbs.2020.05.022

Lim, J. U., Lee, J. H., Kim, J. S., Hwang, Y. II, Kim, T., Yong, S., \& Yoo, K. H. (2017). Comparison of World Health Organization and Asia-Pacific Body Mass Index Classifications in COPD Patients. 2465-2475.

Mahvash, N., Eidy, A., Mehdi, K., Zahra, M. T., Mani, M., \& Shahla, H. (2012). The Effect of Physical Activity on Primary Dysmenorrhea of Female University Students [Pengaruh 
Aktivitas Fisik terhadap Dismenorea Primer pada Mahasiswa Wanita]. World Applied Sciences Journal, 17(10), 1246-1252. Retrieved from https://www.researchgate.net/publication/260288693\%0AThe

Maryam, Ritonga, M. A., \& Istriati. (2016). Relationship between Menstrual Profile and Psychological Stress with Dysmenorrhea [Hubungan antara Siklus Menstruasi dan Stres Psikologis terhadao Dismenorea]. Althea Medical Journal, 3(3), 382-387. https://doi.org/10.15850/amj.v3n3.884

Masturoh, I., \& Temesvari, N. A. (2018). Metode Penelitian Kesehatan. Kementrian Kesehatan Republik Indonesia.

Michael, J., Iqbal, Q., Haider, S., Khalid, A., Haque, N., Ishaq, R., Bashaar, M. (2020). Knowledge and Practice of Adolescent Females about Menstruation and Menstruation Hygiene Visiting a Public Healthcare Institute of Quetta, Pakistan [Pengetahuan dan Praktik pada Remaja Wanita tentang Menstruasi dan Menstrual Hygiene di Institut Kesehatan masyarakat Quetta, Pakistan] . BMC Women's Health, 20(1), 1-8. https://doi.org/10.1186/s12905-019-0874-3

Nuttall, F. Q. (2015). Body Mass Index: Obesity, BMI, and Health: A critical review [Indeks Massa Tubuh: Obesitas, BMI, Kesehatan: Critical Review]. Nutrition Today, 50(3), 117128. https://doi.org/10.1097/NT.0000000000000092

Osuga, Y., Hayashi, K., \& Kanda, S. (2020). Long-term Use of Dienogest for the Treatment of Primary and Secondary Dysmenorrhea [Penggunaan Jangka Panjang Dienogest sebagai Penanganan Dismenorea Primer dan Sekunder]. Journal of Obstetrics and Gynaecology Research, 46(4), 606-617. https://doi.org/10.1111/jog.14209

Pusdatin. (2017). Situasi Kesehatan Reproduksi Remaja (p. 1). p. 1. Retrieved from https://www.kemkes.go.id/download.php?file=download/pusdatin/infodatin/infoda tin reproduksi remaja-ed.pdf

Rafique, N., \& Al-Sheikh, M. H. (2018). Prevalence of Primary Dysmenorrhea and its Relationship with Body Mass Index [Prevalensi Dismenorea Primer dan Hubungan dengan Indeks Massa Tubuh]. Journal of Obstetrics and Gynaecology Research, 44(9), 1773-1778. https://doi.org/10.1111/jog.13697

Smith, R. P. (2018). Dysmenorrhea and Menorrhagia. In Dysmenorrhea and Menorrhagia. https://doi.org/10.1007/978-3-319-71964-1

Vaux-Bjerke, A., Quam, J. B., George, S. M., Sprow, K., Carlson, S. A., Hyde, E. T., \& Olscamp, K. (2018). Physical Activity Guidelines for Americans (2nd ed.). Retrieved from https://www.health.gov/PAGuidelines/

Wallace, S., Keightley, A., \& Gie, C. (2011). Review Dysmenorrhoea. The Obstetrician \& Gynaecologist, 149-154.

Wati, L. R., Arifiandi, M. D., \& Prastiwi, F. (2017). Hubungan Aktifitas Fisik dengan Derajat Dysmenorrhea Primer pada Remaja. Journal of Issues in Midwifery, 1(2549-6581), 76-81.

Weggemans, R. M., Backx, F. J. G., Borghouts, L., Chinapaw, M., Hopman, M. T. E., Koster, A., ... de Geus, E. J. C. (2018). The 2017 Dutch Physical Activity Guidelines [Pedoman Aktivitas Fisik 2017]. International Journal of Behavioral Nutrition and Physical Activity, 15(1), 1-12. https://doi.org/10.1186/s12966-018-0661-9

WHO. (2018). Orientation Programme on Adolescent Health for Health-Care Providers [Program Orientasi pada Kesehatan Remaja untuk Penyedia Layanan Kesehatan]. Retrieved September 25, 2020, from https://www.who.int/maternal_child_adolescent/documents/pdfs/9241591269_op _handout.pdf

Widayanti, L. P., \& Widawati, P. R. (2018). International Conference on Sustainable Health Promotion 2018 Correlation Between Body Mass Index and Dysmenorrhea in Preclinical Female Students Aged 16-24 at The Hang Tuah University Medical Faculty 
, Surabaya. 66-71.

World Health Organization (WHO). (2011). The sexual and Reproductive Health of Younger Adolescents [Kesehatan Seksual dan Reproduksi pada Remaja Awal]. Retrieved October 2, 2020,

from https://www.who.int/reproductivehealth/publications/adolescence/rhr_11_15/en/ 